\title{
Industrial Psychology
}

National Cancer Institute

\section{Source}

National Cancer Institute. Industrial Psychology. NCI Thesaurus. Code C17032.

The branch of applied psychology that is concerned with efficient management of an industrial labor force and especially with problems encountered by workers in a mechanized environment. (Bartleby.com) 